Reserve. Research on the pollination biology and population genetics of $R$. liboense is planned, to support the conservation of the species.

Hunng Chengling and Su Chunhua College of EcoEnvironmental Engineering,Guizhou Minzu University, Guiyang, Guizhou, China.E-mail chenglinghuang@163.com

Tian XIaOling College of Humanities \& Sciences, Guizhou Minzu University, Guiyang, Guizhou, China

CHEN ZHENREN Administration Department of Maolan National Nature Reserve, Libo, China

WEN XIANGYING South China Botanical Garden, the Chinese Academy of Sciences, Guangzhou, China

\section{New legislation threatens wildlife conservation in Poland}

In April 2018 a new Hunting Law (Journal of Laws of the Republic of Poland, 30 March 2018, No. 651) entered into effect in Poland. Poland is one of the last four countries in the EU (in addition to Croatia, Malta and Cyprus) that do not regulate the use of toxic lead ammunition. Each year 400$640 \mathrm{t}$ of lead are introduced into the Polish environment (Niech Żyją, 22 January 2017, http://niechzyja.pl/dokumenty/uwagi-do-zmiany-prawa-lowieckiego-2015.pdf; Kitowski et al., 2017, Ambio, 46, 825-841). Consequently, high concentrations of lead are found in Polish raptors that consume wounded game species or carrion (Komosa \& Kitowski, 2008, Ecological Chemistry and Engineering S, 15, 349-358; Kitowski et al., 2017, op. cit.). The new Hunting Law has not enacted a ban on lead ammunition in any habitat, even in wetlands. There is still no obligation to register animals embedded with lead ammunition that are not recovered. Attempts to ban lead ammunition in Poland so far have been unsuccessful, even though in 2013 Parliament declared that lead ammunition would be banned from hunting shoots on wetlands by 2015 (Polish Parliament 2017, 24 October 2017; http://sejm.gov.pl/sejm7. nsf/InterpelacjaTresc.xsp?key=02849767).

The new Hunting Law ignores current population trends and the status of game birds because cultivation of hunting traditions was considered an important factor in placing individual bird species on the list of game animals that can be legally hunted. This opens up the possibility of unlimited exploitation of species whose numbers are decreasing at an alarming rate in Poland. This applies in particular to the hazel grouse Bonasa bonasia (population 15,000-20,000 pairs in Poland) and Eurasian teal Anas crecca (population 1,300-1,700 pairs; Chodkiewicz et al., 2015, Ornis Polonica, $56,149-189)$. Hunters have already greatly reduced the western capercaillie Tetrao urogallus (population 400-450 adults) and black grouse Lyrurus tetrix (population 250300 pairs), which, despite being protected since 1995, are Critically Endangered species in Poland (Mitrus \& Zbyryt, 2015, Ornis Polonica, 56, 309-327).

Although the new Hunting Law prohibits group hunting in national parks, the Act of 11 March 2004 (amended in July 2017; Journal of Laws of the Republic of Poland, 9 August 2017, No. 1521) on the protection of animal health and the control of infectious diseases in animals legalized this practice within national parks and nature reserves under the pretense of combating African Swine Fever (Pejsak \& Woźniakowski, 2017, Życie Weterynaryjne, 92, 648-651). However, group hunting can contribute to the spread of this disease (Pejsak \& Woźniakowski, 2017, op. cit.).

The Polish Hunter Association (Polski Związek Łowiecki) oversees hunting activities de facto and de jure in Poland. The Association is connected with political and financial elites, and many powerful representatives of the media and business are members. The lobbying centre for the Association within the Polish Parliament (the Parliamentary Team on Culture and Tradition of Hunting) includes 32 deputies and three senators. The strong position of the Association in Parliament makes it difficult to change regulations in favour of wildlife conservation.

IGNACY KITOWSKI State School of Higher Education in Chetm, Chetm, Poland.E-mail ignacyk@autograf.pl

\section{New report of Eurasian otters in Lao}

There is little information on otters in Lao although there are three reported species: smooth-coated otter Lutrogale perspicillata, Asian small-clawed otter Aonyx cinereus and Eurasian otter Lutra lutra. It is also possible that the hairynosed otter Lutra sumatrana is present as it has been found in neighbouring countries (Thailand, Myanmar, Viet Nam and Cambodia).

There were formerly only two recent sources of information on otters in Lao. In 2016 Project Anoulak, a local NGO, produced a report on a preliminary camera-trap survey in the Nakai Nam Theun National Protected Area. In addition to camera-trap surveys, they interviewed local people who provided information on two species locally: 'one with feet like dogs, small and dark, mostly seen in groups of 3-5 individuals' (the Asian small-clawed otter), and 'one with feet like ducks, large, mostly seen in pairs' (the smooth-coated otter). They did not receive reports of the Eurasian otter. The other information came from the Wildlife Conservation Society in April 2018: they confirmed that rangers encounter otters relatively often on one river in the south-east of Nam Et Phou Louey National Park, but they do not know of which species. 